\title{
RECENZE
}

\section{G. Podmarkov, Vvedenije v promyšlennuju sociologiju}

(Socialnyje problemy socialističeskogo promyšlennogo proizvodstva) Izdatel'stvo Mysl', Moskva 1973.

Práce V. G. Podmarkova je dosti rozsáhlá. Má 286 stran vlastního textu, 24 stran príloh a pomèrně rozsáhlou bibliografii. Již na začátku je nutno uvést, že nejde o výrazně původní badatelskou práci autorovu. Práce má spíše podobu velmi dobře napsané příručky či pomůcky, která usiluje podat značné množství informací. Př̀itom nejde o pouhé deskriptivní razení, àutor má snahu o systematický výklad, práce je založena na základních teoretických a metodologických východiscích marxiśmu. Autor se opírá o velké množství prací sovětských autori̊ o preložené práce, využívá i výsledků výzkumů, které byly $v$ posledních letech realizovány. Místy je zřejmá souvislost autorových prístupů $s$ koncepcemi polských a něme:kých (NDR) autorů z oblasti průmyslové sóciologie.

Práce je rozčleněna na deset kapitol. $V^{*}$ rámci této dané základní osnovy autor rożebírá, vysvětluje, komentuie a hołnotí jednak klasické i v jiných učebnic ch či prúručkách obvyklé problémy, jednak využivá predností sovětské soziologie a přináší řadu postřehů, souvislostí a otázek, které nejsou dost obvyklé. To se týká zvláště problematiky sociálního plánování, které se skutečně již stalo jakousi výrazně sovětskou disciplínou, otázek mimopracovního času a volnóho času, vlivu tohoto času a jeho obsahu na pracovní kolektivy aj. Chceme-li dát tomu, kdo se o práci bude zajímat, aspoň základní prohled hlavinich problémů, pak můžeme uvést zejména.tyto: sociologie průmyslu jako věda, podnik jako sociální systém, výrobní kolektiv, obsah práce a funkcionální struktura kolektivu, profese a profesionální skupiny, sociálnè psychologické jevy ve výrobnim kolektivu, řizení a výrobní kolektiv, mimopracovní a volný čas pracovníků podniku, pracovník $\mathrm{v}$ systému sociálních souvislostí, sociální plánování $v$ podniku a závĕrečná problematika poslední kapitoly sociologické výzkumy $\mathrm{v}$ průmyslu.

Jak je vidět $z$ přehledu, jde o značné množství problémů a prri výkladu se autor ještě zabývá dalšími, které logicky navazuji. Všechny kapitoly a pasáže práce nemají proto stejnou úroveň. Některé jsou rozpracovány velmi přesvědčivě, názorně a jistě splní své poslání. Jindy jsou problémy spiše dotčeny, zvláště se to týká iěch otázek, které nejsou ani v sovětské literatuře stejně interpretovány. Předností recenzované práce je u sovětských autorů výrazný teoreticko-kritický prístup. Již v první kapitole autor usiluje o jasné a co možná nejpřesnějši vystižení předmětu soziologie průmyslu. Tato kapitola má nejen význam úvodu do celé práce, její pojetí je dủležité též pro celkovou struktüru a členění spisu. Autor předběžně vymezuje sozio'ogii průmyslu jako aplikovanou společenskou vědu o obsahu a významu "lidskśho faktoru." v průmyslu, tj. jako vĕdu o struktuře, mechanismech a efektivnosti společenských, kolektivních a individuálních činností a vztahů průmyslových pracovn kú.

Další předností práce je analýza pojmú a kategorií, se kterými se často a mnohdy naprosto nereflektovanĕ $\mathrm{v}$ sociologii vưbec a sociologii průmyslu zvláště pracuje. Aurtor se napríklad zamýšlí nad smyslem a 
významem kategorie sociálna, rozlišuje teoretickou a empirickou úroveň přístupu při vytváření systému sociálních kategorií. Nikdy nezapomene zdůraznit význam teoretického přistupu a omezenost faktografie nebo konkrétního výzkumu při řešení otázek, které vyžaduji teoretický a v některých připadech až sociálně filozofický přistup. Obecnou teorii neize vyvodit bezprostředně $z$ faktů.

Základním výchozím tématem celého pojetí sociologie průmyslu je u Podmarkova člověk $v$ soudobé průmyslové výrobě. Vèren svému teoretickému prústupu se autor snaží najít při vymezování předmětu sociologie průmyslu výchozí kategorii, která by byla první analytickou jednotkou. Za takovou analytickou jednotku považuje průmyslový podnik. Ten není jako celek objektem zkoumání sociologie průmyslu. Jde především o společenskou problematiku pođniiku, o zkoumání jeho sociální organizace. Tím, že autor recenzované práce zvolil podnik jako první analytickou jednotku, vytváří si určité východisko, současně však i potíže. Mohou, a to oprávnèně, vzniknout námitky, že ztotožnuje sociologii průmyslu se sociologií podniku, ze stanoviska V. G. Podmarkova je však plně logické, že si vybral podnik jako první analytickou jednotku. Podmarkov totiž neuznává existenci samostatné sociologie podniku, jen podotýká, že $v$ kapitalistických zemích se vyděluje ze sociologie průmyslu sociologie podniku.

Věnoval jsem pozornost první kapitole, protože má teoreticko-koncepční ráz a jeji základni zaměření $\mathrm{v}$ podstatě určuje logickou strukturu celé knihy. Jednotlivé

\section{Člověk - věda - tèchnika}

$\mathrm{V}$ posledni době vyšlo v SSSR mnoho publikací s tematikou vědeckotechnické revoluce. Jednou z významných prací z této oblasti je kniha Človèk - věda - technika (Čelovek - nauka - technika, Moskva 1973; Clověk - věda - technika, Praha-Moskva 1973).

Tato studie je výsledkem spolupráce so- problémy jsou tak předem předznamenány ve výkladu i razení základními teoretiçkými východisky první kapitoly.

Jak již bylo řečeno, nemá kniha ve všech částech stejnou úroveñ, to se týká napríklad kapitoly o kategorii profese i profesionální mobilitě. Naopak zmíněné kapitoly o sociálním plánování, o mimopracovní době a volném čase i o sociálně psychických jevech $\mathrm{v}$ podniku jsou velmi zajímavé, poučné a podnětné. Zde se autor mohl opruit již o velké množství údajů, dat $z$ realizovaných výzkumů sovětské sociologie. Sympatická je snaha autora nedèlat kategorické závěry a zobecnění tam, kde dílčí výsledky pro to nedávají spolehlivý základ.

Když posuzujeme knihu V. G. Podmarkova jako pomůcku či příručku, která má dát přehled a informaci pro studenty, zájemce o sociologii průmyslu a podniku, pro lidi prakticky činné $\mathrm{v}$ oblasti výzku$\mathrm{mu}$ př́mo $\mathrm{v}$ terénu, pak můžeme jednoznačně říci, že jde o dobrý príspěvek pro daný účel. Pro specialistu $\mathrm{v}$ dané oblasti kniha bude zajímavým, ne však ve všech částech plně uspokojivým dokladem toho, jak pristupuji sovětští sociologové $\mathrm{k}$ řešení mnoha významných problémů sociologie průmyslu a jak předkládaji výsledky své práce i svého pojetí širší veřejnosti i specialistům oboru. Podmarkovova kniha je zvláště podnětná pro každého, kdo naprúklad u nás by uvažoval o učební či studijní pomůcce pro odborné i laické zájemce na dané téma. Jistě by se $\mathrm{v}$ mnohém ohledu od autora recenzované práce poučil.

Eduard Urbánek

větské a československé akademií věd. Je kolektivnim dílem pracovníků Filozofického ústavu Akademie věd SSSR (Instituta filosofii Akademii nauk SSSR), Ustavu déjin prírodních věd a techniky Akademie věd SSSR (Instituta istorii jestestvoznanija i techniki Akademii nauk SSSR) a Ustavu pro filozofii a sociologii CSAV. 